\title{
Maternal diets deficient in folic acid and related methyl donors modify mechanisms associated with lipid metabolism in the fetal liver of the rat
}

\author{
Christopher J. McNeil, Susan M. Hay, Garry J. Rucklidge, Martin D. Reid, Gary J. Duncan \\ and William D. Rees* \\ Rowett Institute of Nutrition and Health, The University of Aberdeen, Greenburn Road, Bucksburn, Aberdeen AB21 9SB, UK
}

(Received 11 November 2008 - Revised 6 April 2009 - Accepted 30 April 2009 - First published online 1 July 2009)

Previously we have examined the effects of diets deficient in folic acid ( - F) or folate deficient with low methionine and choline ( - F LM LC) on the relative abundance of soluble proteins in the liver of the pregnant rat. In the present study we report the corresponding changes in the fetal liver at day 21 of gestation. The abundance of eighteen proteins increased when dams were fed the $-\mathrm{F}$ diet. When dams were fed the $-\mathrm{F}$ LM LC diet, thirty-three proteins increased and eight decreased. Many of the differentially abundant proteins in the fetal liver could be classified into the same functional groups as those previously identified in the maternal liver, namely protein synthesis, metabolism, lipid metabolism and proteins associated with the cytoskeleton and endoplasmic reticulum. The pattern was consistent with reduced cell proliferation in the $-\mathrm{F}$ LM LC group but not in the $-\mathrm{F}$ group. Metabolic enzymes associated with lipid metabolism changed in both the $-\mathrm{F}$ and $-\mathrm{F}$ LM LC groups. The mRNA for carnitine palmitoyl transferase were up-regulated and CD36 (fatty acid translocase) down-regulated in the $-\mathrm{F}$ group, suggesting increased mitochondrial oxidation of fatty acids as an indirect response to altered maternal lipid metabolism. In the - F LM LC group the mRNA for acetyl CoA carboxylase was down-regulated, suggesting reduced fatty acid synthesis. The mRNA for transcriptional regulators including PPAR $\alpha$ and sterol response element-binding protein-1c were unchanged. These results suggest that an adequate supply of folic acid and the related methyl donors may benefit fetal development directly by improving lipid metabolism in fetal as well as maternal tissues.

Pregnancy: Methionine: Choline: Folic acid: Endoplasmic reticulum

It is well established that folic acid supplements reduce the risk of neural tube defects ${ }^{(1)}$ and improve the growth of the human fetus ${ }^{(2)}$. Although the detailed mechanism has not been elucidated, folate supplements are believed to improve the flow of methyl groups through the methionine cycle ${ }^{(3,4)}$. Studies of laboratory animals also suggest that altered onecarbon metabolism has long-term effects on cardiovascular and metabolic health of the offspring ${ }^{(5)}$. In rats, the adverse effects of protein restriction can be reversed by the addition of a supplement of either folic acid, or the related amino acid glycine ${ }^{(6-8)}$. Folate-deficient $(-\mathrm{F})$ diets also produce changes in the insulin axis, with a transient increase in the insulin content of the fetal pancreas and a tendency for glucose-stimulated insulin release to be increased in the offspring of rats fed a $-\mathrm{F}$ diet ${ }^{(9)}$.

Previously we have shown that when pregnant rats are fed diets low in folic acid $(-F)$ there are extensive changes in the metabolism of lipids and amino acids ${ }^{(10)}$, and when the diet is additionally low in methionine and choline ( $-\mathrm{F} \mathrm{LM}$ LC) lipids accumulate in the maternal liver ${ }^{(11)}$. Differentially abundant proteins in the soluble fraction of the maternal liver could be allocated into nine functional groups, five involved in metabolic processes, namely the folate-methionine cycle, tyrosine metabolism, protein metabolism, energy metabolism and lipid metabolism and three in cellular processes, namely endoplasmic reticulum function, bile production and antioxidant defence. There were also changes in the levels of mRNA coding for the rate-determining enzymes of fatty acid synthesis and oxidation as well as the transcriptional regulators that control them (PPAR and sterol response element-binding protein-1c). These transcriptional activators are also involved in the development of nonalcoholic fatty liver disease ${ }^{(12)}$. The present experiments were conducted to establish whether there are corresponding changes in the fetal livers of the animals used in our previous studies $^{(10,11)}$. Fetal development may be affected directly by the lack of folate, but since $-\mathrm{F}$ diets produce such large changes in maternal metabolism there is also the possibility of indirect effects caused by changes in the nutrient supply derived from the maternal circulation.

\section{Methods \\ Experimental diets}

The experimental diets were based on the American Institute of Nutrition (AIN)-76 formula ${ }^{(13)}$ and contained $90 \mathrm{~g}$ casein $/ \mathrm{kg}$ supplemented with a mixture of synthetic amino acids

Abbreviations: - F, folate-deficient; - F LM LC, folate-deficient with low methionine and choline; gadd153, growth arrest and DNA damage protein 153. 
equivalent to those found in a further $90 \mathrm{~g}$ casein/ $\mathrm{kg}$ as described previously ${ }^{(10)}$. Folic acid was omitted from the $-\mathrm{F}$ and - F LM LC diets. No additional methionine was added to the $-\mathrm{F}$ LM LC diets (total methionine concentration $2.3 \mathrm{mg}$ methionine $/ \mathrm{kg}$ diet compared with $5.6 \mathrm{mg}$ methionine $/ \mathrm{kg}$ diet in the control) and choline chloride was reduced to $0.1 \%$ (w/w) (compared with $0.2 \%(\mathrm{w} / \mathrm{w})$ in the control).

\section{Animals}

All experimental procedures were approved by the ethical review committee of the Rowett Research Institute and conducted in accordance with the UK Animals (Scientific Procedures) Act, 1986. Female rats of the Rowett hooded strain bred in the Institute were allocated to three groups of eight animals (mean body weight $208 \mathrm{~g}$ ), housed on sawdust bedding and fed control, $-\mathrm{F}$ or $-\mathrm{F}$ LM LC diets ad libitum. The animals were offered the experimental diets for a 2-week adaptation period and then were mated with males of the same strain. The day on which a vaginal plug was detected was denoted day 0 . The female rats were maintained on their corresponding diets until day 21 of gestation, when they were anaesthetised by halothane inhalation and killed by exsanguination. The fetuses were rapidly removed, weighed and killed by decapitation. The fetal livers were rapidly dissected; samples were frozen in liquid $\mathrm{N}_{2}$ and subsequently stored at $-80^{\circ} \mathrm{C}$ until required.

\section{Proteomics}

Samples from a second portion of the same fetal liver used for the RNA preparation were homogenised in buffer containing protease inhibitors and centrifuged for $30 \mathrm{~min}$ at $100000 \mathrm{~g}$ at $4^{\circ} \mathrm{C}$ (Beckman TL-100 centrifuge; Beckman Coulter Ltd, High Wycombe, Bucks, UK) as described previously ${ }^{(11)}$. Proteins in the supernatant fraction ( $300 \mu \mathrm{g}$ from each extract) were separated in the first dimension on BioRad immobilised pH gradient strips (pI 3-10; BioRad, Hemel Hempstead, Herts, UK). Following equilibration with the second dimension buffer, which contained $135 \mathrm{mM}$-iodoacetamide, proteins were separated on an $18 \times 18 \mathrm{~cm}$ SDS polyacrylamide gel at $200 \mathrm{~V}$ for $9.5 \mathrm{~h}$. Molecular weights were determined with a Bio-Rad Precision Plus Protein Mr standard. Gels were stained with colloidal Coomassie brilliant blue, analysed using PDQuest software (v. 7; BioRad) and spots of interest excised with a robotic spot cutter (BioRad). Proteins were digested with trypsin and the identities were determined by matrix-assisted laser desorption/ionisation time of flight (MALDI-TOF) MS (Voyager-DE PRO; Applied Biosystems, Warrington, Cheshire, UK) or by LC/MS/MS (Q-trap; Applied Biosystems). The peptide mass list profiles from both systems were analysed using the Matrix Science 'Mascot' web tool (Matrix Science Ltd, London, UK; http://www. matrixscience.com) using the MSDB database (maintained by the Proteomics Department, Hammersmith Campus, Imperial College London, UK). The Mascot database search criteria allowed one missed cleavage, carbamidomethyl modification of cysteine, partial oxidation of methionine and a charged state of $\mathrm{MH}^{+}$. A Mascot score of at least 50 with $20 \%$ matched peptides covering at least $10 \%$ of the protein sequence was required for a positive identification when the probability value was $P<0 \cdot 05$.

\section{Real-time polymerase chain reaction}

Total RNA was extracted from a portion of fetal liver from one female fetus chosen randomly from the litter, using Trizol reagent (Sigma, Poole, Dorset, UK) as described previously $^{(14)}$. Samples of $200 \mathrm{ng}$ total RNA were reverse transcribed using the TaqMan Reverse Transcription Reagents Kit (Applied Biosystems) primed with random hexamers. The levels of cDNA relative to the $18 \mathrm{~S}$ ribosomal RNA were measured using the SYBR Green real-time PCR kit (Applied Biosystems). The identity of the products was confirmed by sequencing and a calibration curve showed that the response was linear over the range measured. Relative target quantity was calculated from the standard curve and the results expressed as the ratio of the product relative to the product from the $18 \mathrm{~S}$ rRNA.

\section{Statistical analysis}

Data are presented as mean values with their standard errors. The gene expression data (Table 1) were analysed by ANOVA followed by Fischer's multiple comparison test (Genstat 7 statistical package; Lawes Agricultural Trust, Rothamsted Experimental Station, Harpenden, Herts, UK). Images of the proteomic gels (six animals per treatment) were normalised using the PDQuest software (BioRad) to determine the mean corrected spot density, followed by pair-wise comparisons (Student's $t$ test) of each spot on the control gels with either the $-\mathrm{F}$ or the $-\mathrm{F}$ LM LC gels. The spot densities of proteins identified in this preliminary screen were subsequently analysed by ANOVA followed by Fischer's multiple comparison test (Genstat).

\section{Results}

\section{Fetal growth}

The growth and metabolic changes in the animals have been described in detail previously ${ }^{(9-11)}$. Briefly, the fetuses of dams fed the $-\mathrm{F}$ diet were approximately $18 \%$ heavier (4.84 (SEM 0.07) g) than the controls (4.10 (SEM 0.03) g), while those from dams fed the -F LM LC diet were approximately $10 \%$ smaller than the controls (3.71 (SEM 0.07) g; $P=0.004$; ANOVA). The fetal liver in the dams fed the $-\mathrm{F}$ LM LC diets weighed less (0.192 (SEM 0.024) g) compared with those in the control $(0.259$ (SEM 0.023$) \mathrm{g}$ ) and $-\mathrm{F}$ groups $(0.268$ (SEM 0.026) $\mathrm{g} ; P=0.003$; ANOVA). Folate deficiency increased the concentrations of homocysteine, glycine, serine and threonine in the fetal serum but the changes were not as pronounced as in the maternal serum. The $-\mathrm{F}$ diets reduced the folate content of the fetal liver to approximately $30 \%$ of the control ${ }^{(10)}$.

\section{Proteomic analysis of soluble proteins}

Approximately 800 proteins were resolved on the two-dimensional electrophoresis gels of the soluble protein fraction of the fetal liver at day 21 of gestation. Comparisons of the 
Table 1. Proteins associated with methionine metabolism, protein synthesis and proteolysis* (Mean values with their standard errors for six animals per group)

\begin{tabular}{|c|c|c|c|c|c|c|c|c|c|}
\hline \multirow{3}{*}{$\begin{array}{l}\text { Treatment... } \\
\text { Spot no. }\end{array}$} & \multirow[b]{3}{*}{ Protein name } & \multicolumn{6}{|c|}{ Mean pixel density } & \multirow[b]{3}{*}{$P$} & \multirow[b]{3}{*}{$\mathrm{NCBI}$ accession } \\
\hline & & \multicolumn{2}{|c|}{ Control } & \multicolumn{2}{|c|}{$-F$} & \multicolumn{2}{|c|}{$-F$ LM LC } & & \\
\hline & & Mean & SEM & Mean & SEM & Mean & SEM & & \\
\hline \multicolumn{10}{|c|}{ Methyl metabolism } \\
\hline 4403 & S-adenosylhomocysteine hydrolase chain A & $641^{\mathrm{a}}$ & 53 & $761^{\mathrm{a}}$ & 74 & $1025^{\mathrm{b}}$ & 122 & 0.016 & 1B3RB \\
\hline 4510 & Adenosylhomocysteinase & $91^{\mathrm{a}}$ & 21 & $86^{\mathrm{a}}$ & 19 & $194^{\mathrm{b}}$ & 40 & 0.023 & P10760 \\
\hline 4107 & Protein-L-isoaspartate (D-aspartate) $O$-methyltransferase & $80^{\mathrm{a}}$ & 12 & $81^{\mathrm{a}}$ & 18 & $132^{\mathrm{b}}$ & 14 & 0.036 & P22062 \\
\hline 4007 & $\mathrm{PCD} / \mathrm{DCoH}$ & $286^{\mathrm{a}}$ & 87 & $235^{a}$ & 54 & $514^{\mathrm{b}}$ & 74 & 0.045 & EDL93037 \\
\hline 0028 & Uroc1 (urocanase-containing domain) & $80^{\mathrm{a}}$ & 17 & $57^{\mathrm{a}}$ & 7 & $176^{\mathrm{b}}$ & 39 & 0.009 & AAH22133 \\
\hline \multicolumn{10}{|c|}{ Protein synthesis } \\
\hline 3512 & Phenylalanine-tRNA synthetase-like, Mus musculus (mouse) & $1931^{\mathrm{a}}$ & 257 & $2148^{a, b}$ & 177 & $2734^{\mathrm{b}}$ & 204 & 0.054 & AAH79364 \\
\hline 2502 & Translation initiation factor elF-4A1 & $1700^{\mathrm{a}}$ & 218 & $1521^{\mathrm{a}}$ & 106 & $851^{\mathrm{b}}$ & 189 & 0.012 & BC063812 \\
\hline \multicolumn{10}{|c|}{ 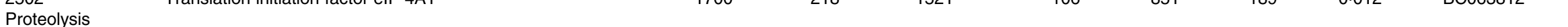 } \\
\hline 5002 & Proteasome endopeptidase complex chain C9 & $9388^{\mathrm{a}}$ & 1195 & $13501^{\mathrm{b}}$ & 1100 & $8243^{a}$ & 465 & 0.006 & $\times 53304$ \\
\hline 5108 & Proteasome endopeptidase complex $\beta$ chain $\mathrm{C} 7$-I & $249^{a}$ & 29 & $351^{\mathrm{a}, \mathrm{b}}$ & 67 & $484^{\mathrm{b}}$ & 73 & 0.031 & S38725 \\
\hline 5602 & Lap3 & $1301^{a}$ & 113 & $1591^{\mathrm{b}}$ & 101 & $1225^{a}$ & 53 & 0.042 & AAH79381 \\
\hline 6812 & Proteasome protein p45/SUG (fragment) & $46^{\mathrm{a}}$ & 8 & $44.5^{a}$ & 8 & $73^{\mathrm{b}}$ & 6 & 0.029 & BAA22935 \\
\hline 1306 & Rat protein 2B28 (mediator of ubiquitin pathway) & $144^{\mathrm{a}}$ & 25 & $177^{\mathrm{a}}$ & 43 & $276^{\mathrm{b}}$ & 96 & 0.017 & AAH06701 \\
\hline 1105 & Cathepsin B precursor & $383^{a}$ & 85 & $498^{a, b}$ & 149 & $801^{\mathrm{b}}$ & 100 & 0.048 & AAA40993 \\
\hline 3002 & Bendless protein (Ube2n) & $134^{\mathrm{a}}$ & 24 & $146^{\mathrm{a}}$ & 23 & $241^{\mathrm{b}}$ & 36 & 0.034 & Q9EQX9 \\
\hline
\end{tabular}

- F, folate-deficient diet; -F LM LC, folate-deficient diet with low methionine and choline; NCBI, National Center for Biotechnology Information; PCD, pterin-4a-carbinolamine dehydratase; DCoH, dimerisation cofactor of hepatic nuclear factor-1; elF-4A1, eukaryotic initiation factor-4A1; Lap3, leucine aminopeptidase 3; SUG, sugarbabe; Ube2n, ubiquitin-conjugating enzyme E2.

${ }^{\mathrm{a}, \mathrm{b}}$ Mean values within a row with unlike superscript letters were significantly different $(P<0.05)$.

* Data were analysed by one-way ANOVA followed by Fischer's unprotected test. 
relative abundance of proteins from the liver of animals fed the control diet with those fed the $-\mathrm{F}$ diet showed that eighteen proteins were up-regulated $(P<0.05$; Student's $t$ test). There were no proteins down-regulated in the fetal livers of dams fed the $-\mathrm{F}$ diet. Comparisons of the patterns from animals fed the $-\mathrm{F}$ LM LC diet with the control showed that thirty-three proteins were up-regulated and eight proteins were down-regulated $(P<0 \cdot 05$; Student's $t$ test). All of the proteins identified in the initial analysis were sequenced by MS and allocated to different functional groups. Table 1 shows the proteins associated with methionine metabolism, protein synthesis and proteolysis. Table 2 shows the proteins associated with energy metabolism, fat metabolism and cell signalling. Table 3 shows the proteins associated with endoplasmic reticulum function and $\mathrm{Fe}$ metabolism. Table 3 also includes a small number of proteins which could not be allocated to these groups. A number of proteins produced more than one spot. This may be the result of a number of factors which are either technical factors such as proteolysis during sample preparation and biological factors including differences in post-translational processing.

\section{Gene expression}

The levels of mRNA coding for enzymes associated with lipid metabolism and the transcriptional regulators that control them are shown in Table 4. The mRNA for acetyl CoA carboxylase, associated with fatty acid synthesis, was decreased by approximately $23 \%$ in the livers of fetuses fed the -F LM LC diet when compared with the control. The mRNA for fatty acid synthase also tended to be approximately $40 \%$ lower in the $-\mathrm{F}$ LM LC group. The $-\mathrm{F}$ diet had no effect. In contrast, the levels of the mRNA for liver type carnitine palmitoyl transferase- 1 increased $273 \%$ in the $-\mathrm{F}$ group but was unchanged in the $-\mathrm{F}$ LM LC group when compared with the control. The mRNA for acyl CoA oxidase was unchanged in all groups. There was a $42 \%$ decrease in the mRNA coding for the fatty acid transporter CD36 (fatty acid translocase) in the $-F$ group whereas the levels were unchanged in the $-\mathrm{F}$ LM LC group.

There were no changes in the mRNA coding for the main transcriptional regulators of hepatic lipid metabolism (PPAR $\alpha$, liver $\mathrm{X}$ receptor- $\alpha$, sterol response element-binding protein-1c, and the CCAAT/enhancer-binding proteins $\mathrm{C} / \mathrm{EBP} \alpha$ and $\mathrm{C} /$ $\mathrm{EBP} \beta$ ) in either the $-\mathrm{F}$ or $-\mathrm{F}$ LM LC groups. The levels of the mRNA coding for growth arrest and DNA damage protein 153 (gadd153) were not significantly different when the uncorrected data were analysed by ANOVA $(P=0 \cdot 240)$. However, litter size was found to be a strong covariate $(P=0 \cdot 007)$. This correction reduced the overall variance and when it was included in the analysis, the levels of the mRNA for gadd153 were unchanged in the $-\mathrm{F}$ group but increased by $33 \%$ in the -F LM LC group compared with the control.

\section{Discussion}

The relative abundance of proteins in the soluble fraction of the liver is determined by a number of factors, including rates of production, sequestration into other fractions and changes in post-translational processing, giving a unique insight into the impact of maternal diet on numerous processes occurring within a tissue. Many of the differentially abundant proteins in the fetal liver can be classified into the same functional groups as those previously identified in the maternal liver ${ }^{(11)}$, namely protein synthesis, metabolism, lipid metabolism and proteins associated with the cytoskeleton and endoplasmic reticulum. Similar classes of proteins have also been identified as being differentially abundant in the livers of adult animals fed $-\mathrm{F}$ rations ${ }^{(15)}$ or following druginduced steatosis ${ }^{(16)}$. Two additional groups of proteins were differentially abundant in the fetal liver: a group of proteins associated with cell signalling and one associated with $\mathrm{Fe}$ metabolism. Additionally a group of proteins associated with oxidative stress, which were found to be elevated in the adult liver, do not appear to be differentially abundant in the fetal liver. Only one of the proteins up-regulated in the fetal liver was found to be common to both the $-\mathrm{F}$ and $-\mathrm{F}$ LM LC groups, although the levels of a further seven proteins in the $-\mathrm{F}$ group were intermediate between the control and -F LM LC groups, suggesting that there may have been small change in these proteins as a result of the folate deficiency alone. There were no common proteins down-regulated in the $-\mathrm{F}$ and $-\mathrm{F}$ LM LC groups although there was one protein with levels intermediate between the control and - F LM LC groups.

Our previous studies have suggested that the reduction in fetal growth observed in the animals fed the $-\mathrm{F}$ LM LC diet is due to the restricted availability of sulfur amino acids ${ }^{(9)}$. The changes in the abundance of proteins associated with protein synthesis, proteolysis and metabolism in the fetal livers of this group are consistent with this proposition. For example, the eukaryotic initiation factor-4A1 (eIF4-A1) is unchanged in the $-\mathrm{F}$ group whereas it is down-regulated in the -F LM LC group. At the same time, DCoH (dimerisation cofactor of hepatic nuclear factor-1), associated with the transcriptional response to amino acid deficiency ${ }^{(17)}$ and p45/SUG, part of the proteosome which plays a critical role in supplying amino acids for sustained protein synthesis in response to amino acid deficiency ${ }^{(18)}$, are up-regulated in the -F LM LC group. The increase in the levels of the mRNA for gadd153, which increases in response to amino acid deficiency in cell cultures ${ }^{(19)}$, also suggests that there is a limitation in the amino acid supply in the -F LM LC group but not in the $-\mathrm{F}$ group.

The reduced growth of the $-\mathrm{F}$ LM LC group may also underlie some of the changes in the abundance of proteins associated with cell signalling. The up-regulation of growth factor receptor bound protein-2 (Grb-2), phosphohistidine phosphatase-1 (Phpt-1) and Rho-GDP dissociation inhibitor (Rho-GDI) suggests that there are important changes in the signalling from activated cell surface receptors, affecting processes such as epithelial morphogenesis, angiogenesis and vasculogenesis ${ }^{(20-22)}$. Similar changes in cell-cell interactions and signalling via mitogen-activated protein (MAP) kinase and extracellular signal-regulated kinase (ERK) signalling pathways are observed in microarray studies of the fetal liver of dams fed low-protein diets ${ }^{(23)}$, suggesting that there may be changes in the three-dimensional structure of the developing liver. However, the abundance of these signalling proteins is not altered in the $-\mathrm{F}$ group, suggesting that folate deficiency alone does not have the same effect on signalling as the combined deficiency of all three methyl donors. In the $-\mathrm{F}$ 
Table 2. Proteins associated with energy metabolism, fat metabolism and cell signalling*

(Mean values with their standard errors for six animals per group)

\begin{tabular}{|c|c|c|c|c|c|c|c|c|c|}
\hline \multirow{3}{*}{$\begin{array}{l}\text { Treatment. } \\
\text { Spot no. }\end{array}$} & \multirow[b]{3}{*}{ Protein name } & \multicolumn{6}{|c|}{ Mean pixel density } & \multirow[b]{3}{*}{$P$} & \multirow[b]{3}{*}{ NCBI accession } \\
\hline & & \multicolumn{2}{|c|}{ Control } & \multicolumn{2}{|c|}{$-F$} & \multicolumn{2}{|c|}{$-F$ LM LC } & & \\
\hline & & Mean & SEM & Mean & SEM & Mean & SEM & & \\
\hline \multicolumn{10}{|c|}{ Energy metabolism } \\
\hline 6411 & Malate dehydrogenase, cytoplasmic & $324^{\mathrm{a}}$ & 19 & $588^{\mathrm{b}}$ & 33 & $416^{a, b}$ & 64 & 0.063 & \\
\hline 3202 & Cytosolic malate dehydrogenase & $330^{\mathrm{a}}$ & 97 & $384^{\mathrm{a}}$ & 76 & $858^{\mathrm{b}}$ & 154 & 0.008 & AAH59124 \\
\hline 4505 & Isocitrate dehydrogenase (NADP) & $6992^{\mathrm{a}}$ & 488 & $8940^{\mathrm{b}}$ & 722 & $5804^{\mathrm{a}}$ & 426 & 0.004 & A54756 \\
\hline 3307 & UDP-glucose 4-epimerase & $161^{\mathrm{a}}$ & 37 & $361^{\mathrm{b}}$ & 80 & $375^{\mathrm{b}}$ & 75 & 0.051 & P18645 \\
\hline 2716 & $\alpha$-Enolase & $169^{\mathrm{a}}$ & 38 & $92^{\mathrm{a}}$ & 36 & $397^{\mathrm{b}}$ & 118 & 0.025 & P04764 \\
\hline 2009 & $\alpha$-Enolase & $61^{\mathrm{a}}$ & 36 & $49^{\mathrm{a}}$ & 49 & $209^{\mathrm{b}}$ & 16 & 0.036 & AAH63174 \\
\hline 4808 & Aldehyde dehydrogenase 1 family, member B1 (mouse) & $18 \cdot 5^{a}$ & 3 & $11 \cdot 3^{\mathrm{a}}$ & 1 & $29 \cdot 7^{\mathrm{b}}$ & 5 & 0.007 & Q9CZS1 \\
\hline 4613 & Aldehyde dehydrogenase 1 family, member B1 & $672^{\mathrm{a}}$ & 56 & $964^{\mathrm{b}}$ & 109 & $607^{\mathrm{a}}$ & 25 & 0.007 & AAH81884 \\
\hline \multicolumn{9}{|c|}{ Fat metabolism } & AAS75815 \\
\hline 2104 & Phosphatase $2 \mathrm{~A}$ inhibitor & $506^{\mathrm{a}}$ & 83 & $640^{\mathrm{a}, \mathrm{b}}$ & 197 & $962^{\mathrm{b}}$ & 136 & 0.093 & Q63945 \\
\hline 2302 & Farnesyl-pyrophosphate synthetase (cholesterol synthesis) & $476^{a, b}$ & 55 & $626^{\mathrm{a}}$ & 54 & $349^{b}$ & 74 & 0.023 & AAH59125 \\
\hline 3206 & PEBP & $2734^{\mathrm{a}}$ & 162 & $3715^{\mathrm{b}}$ & 322 & $2372^{\mathrm{a}}$ & 123 & 0.002 & P31044 \\
\hline 3501 & 4-Trimethylaminobutyraldehyde dehydrogenase & $342^{\mathrm{a}}$ & 44 & $493^{\mathrm{b}}$ & 70 & $314^{a}$ & 26 & 0.05 & Q9JLJ3 \\
\hline 5203 & Dienoyl-CoA isomerase & $1010^{\mathrm{a}}$ & 67 & $1458^{\mathrm{b}}$ & 204 & $1069^{a, b}$ & 136 & 0.081 & $1 \mathrm{DCIA}$ \\
\hline 6109 & Fatty acid-binding protein 5 & $128^{\mathrm{a}}$ & 17 & $138^{\mathrm{a}}$ & 138 & $266^{\mathrm{b}}$ & 266 & 0.016 & S83247 \\
\hline \multicolumn{10}{|c|}{ Cell signalling } \\
\hline 3106 & Grb2 (Rattus norvegicus) (Ash-m) & $358^{\mathrm{a}}$ & 88 & $371^{\mathrm{a}}$ & 101 & $758^{\mathrm{b}}$ & 134 & 0.03 & BAA08645 \\
\hline 8101 & Rho-GDl $\alpha$ & $238^{\mathrm{a}}$ & 68 & $450^{\mathrm{a}, \mathrm{b}}$ & 105 & $574^{\mathrm{b}}$ & 67 & 0.027 & AAH04732 \\
\hline 1016 & Similar to phosphohistidine phosphatase 1 & $82^{\mathrm{a}}$ & 22 & $79^{\mathrm{a}}$ & 17 & $209^{\mathrm{b}}$ & 29 & 0.002 & BAB24222 \\
\hline 3402 & Ran-GTPase activating protein 1 (predicted) & $797^{a, b}$ & 92 & $1068^{\mathrm{b}}$ & 111 & $762^{\mathrm{a}}$ & 64 & 0.067 & AAH82056 \\
\hline 2004 & Rab-GDP dissociation inhibitor- $\beta$ & $706^{\mathrm{a}}$ & 56 & $1121^{\mathrm{b}}$ & 142 & $792^{\mathrm{a}}$ & 116 & 0.034 & P50399 \\
\hline
\end{tabular}

- F, folate-deficient diet; - F LM LC, folate-deficient diet with low methionine and choline; NCBI, National Center for Biotechnology Information; PEBP, phosphatidylethanolamine-binding protein; Grb2, growth factor receptor-bound

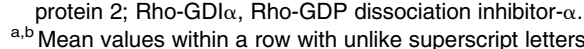

. Mean values wignificantly different $(P<0.05)$.

* Data were analysed by one-way ANOVA followed by Fischer's unprotected test. 
Table 3. Proteins associated with endoplasmic reticulum (ER) function and iron metabolism, and other proteins* (Mean values with their standard errors for six animals per group)

\begin{tabular}{|c|c|c|c|c|c|c|c|c|c|}
\hline \multirow{3}{*}{$\begin{array}{l}\text { Treatment... } \\
\text { Spot no. }\end{array}$} & \multirow[b]{3}{*}{ Protein name } & \multicolumn{6}{|c|}{ Mean pixel density } & \multirow[b]{3}{*}{$P$} & \multirow[b]{3}{*}{$\mathrm{NCBI}$ accession } \\
\hline & & \multicolumn{2}{|c|}{ Control } & \multicolumn{2}{|c|}{$-F$} & \multicolumn{2}{|c|}{$-F$ LM LC } & & \\
\hline & & Mean & SEM & Mean & SEM & Mean & SEM & & \\
\hline \multicolumn{10}{|c|}{ ER and cytoskeleton } \\
\hline 1812 & Transitional endoplasmic reticulum ATPase & $339^{a}$ & 83 & $344^{\mathrm{a}}$ & 123 & $711^{\mathrm{b}}$ & 69 & 0.02 & A55190 \\
\hline 2806 & Transitional endoplasmic reticulum ATPase & $640^{\mathrm{a}}$ & 66 & $525^{\mathrm{a}}$ & 93 & $943^{b}$ & 91 & 0.009 & A55190 \\
\hline 1210 & Annexin A4 (36 kDa) & $75^{\mathrm{a}}$ & 11 & $94 \cdot 6^{\mathrm{a}}$ & 24 & $157 \cdot 2^{\mathrm{b}}$ & 15 & 0.009 & NP_077069 \\
\hline 2109 & Apolipoprotein A-I & $79^{\mathrm{a}}$ & 11 & $74^{\mathrm{a}}$ & 19 & $170^{\mathrm{b}}$ & 24 & 0.003 & NP_036870 \\
\hline 2003 & S100 Ca-binding protein A8 (calgranulin A) & $282^{\mathrm{a}}$ & 39 & $272^{\mathrm{a}}$ & 72 & $572^{\mathrm{b}}$ & 87 & 0.009 & P50115 \\
\hline 4209 & Regucalcin & $170^{\mathrm{a}, \mathrm{b}}$ & 29 & $251^{\mathrm{b}}$ & 51 & $128^{\mathrm{a}}$ & 22 & 0.080 & Q03336 \\
\hline 3510 & Tubb5 & $1023^{a}$ & 66 & $1276^{\mathrm{b}}$ & 83 & $923^{\mathrm{a}}$ & 83 & 0.016 & AAH60540 \\
\hline 4718 & Moesin (membrane-organising extension spike protein) & $186^{\mathrm{a}}$ & 55 & $167^{\mathrm{a}}$ & 37 & $384^{\mathrm{b}}$ & 77 & 0.037 & O35763 \\
\hline 1602 & ER-60 protease & $7878^{a}$ & 620 & $6345^{a}$ & 670 & $10995^{\mathrm{b}}$ & 1338 & 0.009 & D63378 \\
\hline 5105 & DnaK-type molecular chaperone $\mathrm{Hsp} 70 \cdot 3$ & $115 \cdot 8^{\mathrm{a}}$ & 10 & $158^{\mathrm{a}, \mathrm{b}}$ & 19 & $171.1^{\mathrm{b}}$ & 15 & 0.032 & P55063 \\
\hline 5403 & DnaK-type molecular chaperone Hsp72-ps1 & $3920^{\mathrm{a}, \mathrm{b}}$ & 350 & $5020^{\mathrm{b}}$ & 672 & 3389 & 127 & 0.056 & AAH98914 \\
\hline 2503 & DnaK-type molecular chaperone Grp75 precursor & $665^{\mathrm{a}, \mathrm{b}}$ & 84 & $482^{\mathrm{a}}$ & 62 & $977^{\mathrm{b}}$ & 170 & 0.024 & 156581 \\
\hline 4002 & Hip (co-chaperone in the Hsc70/Hsp40 reaction cycle) & $984^{\mathrm{a}}$ & 124 & $1700^{\mathrm{b}}$ & 117 & $1008^{\mathrm{a}}$ & 111 & $<0.001$ & CAA57546 \\
\hline 4405 & Dnajb11, DnaJ (Hsp40) homologue, subfamily B, member 11 & $126^{\mathrm{a}}$ & 21 & $188^{b}$ & 23 & $98^{\mathrm{a}}$ & 9 & 0.015 & AY387070 \\
\hline 4504 & Chaperonin containing TCP1 & $1044^{a, b}$ & 155 & 1392 & 110 & 968 & 58 & 0.06 & AAH83650 \\
\hline \multicolumn{10}{|c|}{ Fe metabolism } \\
\hline 4001 & Ferritin light chain & $187^{\mathrm{a}}$ & 58 & $170^{\mathrm{a}}$ & 170 & $521^{b}$ & 521 & 0.004 & AAH61525 \\
\hline 4407 & Liver regeneration-related protein LRRG03 (transferrin) & $288^{\mathrm{a}}$ & 55 & $301^{a}$ & 72 & $195^{\mathrm{b}}$ & 46 & 0.033 & AAQ91040 \\
\hline \multicolumn{10}{|c|}{ 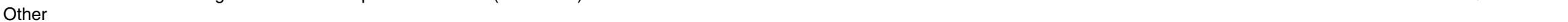 } \\
\hline 2721 & Rat $\alpha$ 1-fetoprotein & $745^{\mathrm{a}}$ & 51 & $520^{\mathrm{a}, \mathrm{b}}$ & 135 & $417^{\mathrm{b}}$ & 92 & 0.064 & V01254 \\
\hline 3603 & Protein disulfide isomerase-associated protein 3 & $843^{\mathrm{a}}$ & 85 & $821^{\mathrm{a}}$ & 142 & $432^{b}$ & 36 & 0.016 & P11598 \\
\hline 3608 & Epoxide hydrolase 2, cytoplasmic & $684^{\mathrm{a}, \mathrm{b}}$ & 76 & $829^{\mathrm{a}}$ & 102 & $545^{\mathrm{b}}$ & 36 & 0.065 & AAH85732 \\
\hline 3609 & Serum albumin precursor & $3192^{\mathrm{a}}$ & 160 & $3142^{a}$ & 335 & $2420^{\mathrm{b}}$ & 156 & 0.052 & P020770 \\
\hline 4605 & T-kininogen I precursor & $500^{\mathrm{a}}$ & 66 & $1013^{\mathrm{b}}$ & 168 & $594^{\mathrm{a}, \mathrm{b}}$ & 184 & 0.049 & AAA41489 \\
\hline 5204 & Ribonuclease A family 4 (Rnase4) & $842^{\mathrm{a}}$ & 62 & $1361^{\mathrm{b}}$ & 193 & $804^{\mathrm{a}}$ & 47 & 0.006 & AAH05569 \\
\hline 7207 & Alloantigen $\mathrm{F}$ & $72^{\mathrm{a}}$ & 85 & $150^{\mathrm{b}}$ & 66 & $191^{\mathrm{b}}$ & 181 & 0.041 & AAA40740 \\
\hline
\end{tabular}

- F, folate-deficient diet; - F LM LC, folate-deficient diet with low methionine and choline; NCBI, National Center for Biotechnology Information; Hsp, heat shock protein; Grp75, glucose-regulated protein 75; TCP1, t-complex 1. Mean values within a row with unlike superscript letters were significantly different $(P<0.05)$

*Data were analysed by one-way ANOVA followed by Fischer's unprotected test. 
Table 4. Gene expression in the fetal liver (relative expression in arbitrary units)*

(Mean values with their standard errors)

\begin{tabular}{|c|c|c|c|c|c|c|c|}
\hline \multirow[t]{2}{*}{ Treatment... } & \multicolumn{2}{|c|}{ Control ( $n$ 5) } & \multicolumn{2}{|c|}{$-\mathrm{F}(n 5)$} & \multicolumn{2}{|c|}{$\begin{array}{c}-\mathrm{F} \text { LM LC } \\
(n 7)\end{array}$} & \multirow[b]{2}{*}{$P$} \\
\hline & Mean & SEM & Mean & SEM & Mean & SEM & \\
\hline$A C C-1$ & $26 \cdot 4^{\mathrm{a}}$ & 1.5 & $25 \cdot 5^{a}$ & 0.8 & $19 \cdot 5^{\mathrm{b}}$ & $2 \cdot 2$ & 0.028 \\
\hline FAS & $1.5^{\mathrm{a}}$ & 0.1 & $1.2^{\mathrm{a}}$ & 0.2 & $0.9^{\mathrm{b}}$ & $0 \cdot 1$ & 0.053 \\
\hline L-CPT-1 & $11 \cdot 8^{\mathrm{a}}$ & $2 \cdot 6$ & $32 \cdot 3^{\mathrm{b}}$ & 8.7 & $14 \cdot 3^{a}$ & $2 \cdot 6$ & 0.029 \\
\hline ACO & 1.4 & 0.12 & 1.8 & 0.2 & 1.5 & 0.3 & 0.607 \\
\hline CD36 & $4 \cdot 5^{\mathrm{a}}$ & 0.41 & $2 \cdot 7^{\mathrm{b}}$ & 0.5 & $3.9^{a}$ & 0.5 & 0.049 \\
\hline PPAR $\alpha$ & $2 \cdot 0$ & 0.1 & 1.9 & 0.1 & $2 \cdot 0$ & 0.1 & 0.755 \\
\hline SREBP-1C & 1.2 & 0.1 & $1 \cdot 2$ & 0.2 & $1 \cdot 1$ & 0.1 & 0.651 \\
\hline $\operatorname{LXR} \alpha$ & 1.5 & 0.1 & 1.4 & 0.1 & $1 \cdot 6$ & 0.2 & 0.572 \\
\hline $\mathrm{C} / \mathrm{EBP} \alpha$ & $32 \cdot 0$ & 1.3 & $30 \cdot 3$ & $3 \cdot 1$ & $28 \cdot 1$ & 3.4 & 0.652 \\
\hline $\mathrm{C} / \mathrm{EBP} \beta$ & 4.0 & 0.5 & $5 \cdot 3$ & $1 \cdot 0$ & $6 \cdot 6$ & 1.4 & 0.222 \\
\hline gadd153† & $33.9^{a}$ & $4 \cdot 6$ & $32.9^{a}$ & 3.4 & $45 \cdot 2^{b}$ & 4.4 & 0.019 \\
\hline
\end{tabular}

- F, folate-deficient diet; - F LM LC, folate-deficient diet with low methionine and choline; ACC-1, acetyl CoA carboxylase; FAS, fatty acid synthase; L-CPT-1, liver type carnitine palmitoyl transferase; ACO, acyl CoA oxidase; CD36, fatty acid translocase; SREBP-1c, sterol response element-binding protein; LXR $\alpha$, liver $X$ receptor nuclear receptor subfamily 1 , group $\mathrm{H}$, member 3; $\mathrm{C} / \mathrm{EBP} \alpha$, CCAAT/enhancer-binding protein $\alpha$; C/EBP $\beta$, CCAAT/ enhancer-binding protein $\beta ;$ gadd153, growth arrest and DNA damage protein 153.

${ }^{a, b}$ Mean values within a row with unlike superscript letters were significantly different $(P<0.05)$

* Data were analysed by ANOVA followed by Fischer's unprotected test. The primer sequences have been described previously ${ }^{(11,29-31)}$ except for CD36; forward 5'-GGA AAG TTA TTG CGA CAT GAT TAA TG-3' and reverse 5'-GGA AAG AAC CTC AGT GTT TGA GAC TTC-3'.

†Corrected for litter size as a covariate: control $=15.0$ (SEM 0.6$),-F=14.0$ (SEM 13.1), - F LM LC $=13.1$ (SEM 0.9); regression coefficient $=4.90$ (SEM 1.54) $(P=0.007)$.

group the Ran-GTPase-binding protein and the Rab-GDP dissociation inhibitor are both increased. These proteins are associated with the regulation of several cellular processes including nucleo-cytoplasmic transport, cell-cycle progression and post-mitotic nuclear assembly ${ }^{(24)}$; however, the functional significance of these changes is not clear.

Proteins associated with the cytoskeleton and the endoplasmic reticulum are differentially abundant in the soluble fraction of both the fetal and maternal livers. Amongst the proteins in this group, the endoplasmic reticulum ATPase, apoA1 and Ca-binding proteins have all been associated with packaging of VLDL ${ }^{(25)}$. Another differentially abundant protein, the endoplasmic reticulum-localised protein ER-60, which has both proteolytic and chaperone activities, has been shown to associate with newly synthesised apoB ${ }^{(26)}$. Changes in the abundance of annexin A4, which belongs to a class of $\mathrm{Ca}^{2+}$-binding proteins that bind acidic phospholipids ${ }^{(27)}$, suggest that there may also be changes in exocytosis. Overall the changes in this group of proteins suggest that the maternal diet deficient in folic acid and low in methionine and choline ( - F LM LC) is modifying the function of the endoplasmic reticulum in the fetal liver in a similar way to that seen in the maternal liver. There is no evidence that these processes are affected in the $-F$ group, suggesting that the methyl supply is sufficient to support these processes.

There are also changes in groups of proteins associated with metabolism and especially the metabolism of lipids in both the $-\mathrm{F}$ and $-\mathrm{F}$ LM LC groups. Proteins in these groups, including cytosolic malate dehydrogenase, enolase and fatty acidbinding proteins, undergo similar changes in abundance in the maternal liver. These changes suggest that both $-\mathrm{F}$ diets and diets deficient in all three methyl donors (-F LM LC) are altering lipid metabolism in the fetal liver. However, analysis of mRNA associated with the regulation of lipid metabolism in adults suggests that there are important differences. The present study shows that the mRNA for the sterol response element-binding protein-1c and acetyl CoA carboxylase (fatty acid synthesis), both of which are downregulated in the maternal liver, are unchanged in the fetal liver. There is also no change in the PPAR $\alpha$ which is up-regulated in the maternal liver in the $-\mathrm{F} \mathrm{LM} \mathrm{LC}$ group $^{(11)}$. There is also no change in the levels of other transcriptional activators associated with lipid metabolism, such as liver X receptor and the CCAAT/enhancer-binding proteins in the fetal liver. The up-regulation of the mRNA for carnitine palmitoyl transferase in the fetal livers of the $-F$ group suggests an increase in mitochondrial fatty acid oxidation which does not occur in the - F LM LC group. The mRNA for acetyl CoA carboxylase and fatty acid synthase is reduced by approximately $20 \%$ in the $-\mathrm{F}$ LM LC group and is consistent with a down-regulation of fatty acid production. There are also changes in the abundance of proteins specifically associated with fat metabolism and these are consistent with the changes in mRNA levels. For example, the changes in the cytoplasmic malate dehydrogenase (malate aspartate shuttle), $\alpha$-enolase and mitochondrial aldehyde dehydrogenase in the $-\mathrm{F}$ LM LC group all suggest a reduction in fatty acid synthesis. These data suggest that there are some similarities in the effects of the deficient diets, with a decrease in fatty acid synthesis in both the maternal and fetal livers of animals fed the - F LM LC diet. However, the data suggest that there are also some important differences, especially in animals fed the $-\mathrm{F}$ diet, which increase fatty acid oxidation in the fetal liver but have no effect in the maternal liver.

These results suggest that an adequate supply of folic acid and the related methyl donors may benefit fetal development directly by improving methionine cycle activity and hence lipid metabolism in fetal as well as maternal tissues. The data suggest that in the case of folate deficiency $(-F)$ the main effects are on lipid metabolism in the maternal system with only compensatory changes in fatty acid oxidation in the fetal liver, whereas when folate deficiency is combined with a shortage of the related methyl donors then there is a more widespread change in fat metabolism and effects on the endoplasmic reticulum in both maternal and fetal livers. The effect of folate supplements on lipid accumulation, especially in humans, is unknown; however, it is increasingly clear that the formation of lipid deposits within organs is a risk factor for many diseases ${ }^{(28)}$. The potential for folate deficiency to reduce this accumulation suggests several potential links to abnormal fetal development and subsequent disease. Folic acid and related methyl donors may have a hitherto unknown role in fetal lipid metabolism, which may be an important link between folate status, fetal growth and neural development in human pregnancies.

\section{Acknowledgements}

The present study was supported by the Rural and Environment Research and Analysis Directorate of The Scottish 
Government as part of the core funds of the Rowett Institute for Health and Nutrition and by the European Union sixth Framework programme EARNEST (CT-2005-007036). We wish to express our thanks to staff from the Bioresources Unit for animal care and to Dr C. Mayer (Biomathematics and Statistics, Scotland) for advice on the statistical analysis.

W. D. R. and C. J. M. designed the research; S. M. H., C. J. M. and W. D. R. performed the research; R. J. G., M. J. R. and G. J. D. carried out the gel electrophoresis and MS; C. J. M., S. M. H. and W. D. R. analysed the data; W. D. R. and C. J. $\mathrm{M}$. wrote the paper.

The authors declare no conflict of interest.

\section{References}

1. De Wals P, Tairou F, Van Allen MI, et al. (2007) Reduction in neural-tube defects after folic acid fortification in Canada. $N$ Engl J Med 357, 135-142.

2. Relton CL, Pearce MS \& Parker L (2005) The influence of erythrocyte folate and serum vitamin $\mathrm{B}_{12}$ status on birth weight. Br J Nutr 93, 593-599.

3. Anna E \& Beaudin P (2007) Folate-mediated one-carbon metabolism and neural tube defects: balancing genome synthesis and gene expression. Birth Defects Res C Embryo Today 81, 183-203.

4. Dunlevy LP, Burren KA, Mills K, et al. (2006) Integrity of the methylation cycle is essential for mammalian neural tube closure. Birth Defects Res A Clin Mol Teratol 76, 544-552.

5. Burdge GC, Hanson MA, Slater-Jefferies JL, et al. (2007) Epigenetic regulation of transcription: a mechanism for inducing variations in phenotype (fetal programming) by differences in nutrition during early life? Br J Nutr 97, 1036-1046.

6. Lillycrop KA, Phillips ES, Jackson AA, et al. (2005) Dietary protein restriction of pregnant rats induces and folic acid supplementation prevents epigenetic modification of hepatic gene expression in the offspring. J Nutr 135, 1382-1386.

7. Torrens C, Brawley L, Anthony FW, et al. (2006) Folate supplementation during pregnancy improves offspring cardiovascular dysfunction induced by protein restriction. Hypertension 47, 982-987.

8. Jackson AA, Dunn RL, Marchand MC, et al. (2002) Increased systolic blood pressure in rats induced by a maternal lowprotein diet is reversed by dietary supplementation with glycine. Clin Sci (Lond) 103, 633-639.

9. Maloney CA, Hay SM \& Rees WD (2009) The effects of feeding rats diets deficient in folic acid and related methyl donors on the blood pressure and glucose tolerance of the offspring. Br J Nutr 101, 1333-1340.

10. Maloney CA, Hay SM \& Rees WD (2007) Folate deficiency during pregnancy impacts on methyl metabolism without affecting global DNA methylation in the rat fetus. $\mathrm{Br} \mathrm{J} \mathrm{Nutr}$ 97, 1090-1098.

11. McNeil CJ, Hay SM, Rucklidge G, et al. (2008) Disruption of lipid metabolism in the liver of the pregnant rat fed folate deficient and methyl donor deficient diets. Br J Nutr 99, $262-271$.

12. Higuchi N, Kato M, Shundo Y, et al. (2008) Liver X receptor in cooperation with SREBP-1c is a major lipid synthesis regulator in nonalcoholic fatty liver disease. Hepatol Res 38, 1122-1129.

13. American Institute of Nutrition (1977) Report of the American Institute of Nutrition ad hoc committee on standards for nutritional studies. J Nutr 107, 340-348.
14. Maloney CA, Lilley C, Cruickshank M, et al. (2005) The expression of growth-arrest genes in the liver and kidney of the protein-restricted rat fetus. Br J Nutr 94, 12-18.

15. Chanson A, Sayd T, Rock E, et al. (2005) Proteomic analysis reveals changes in the liver protein pattern of rats exposed to dietary folate deficiency. J Nutr 135, 2524-2529.

16. Meneses-Lorente G, Watt A, Salim K, et al. (2006) Identification of early proteomic markers for hepatic steatosis. Chem Res Toxicol 19, 986-998.

17. Marten NW, Hsiang CH, Yu L, et al. (1999) Functional activity of hepatocyte nuclear factor-1 is specifically decreased in amino acid-limited hepatoma cells. Biochim Biophys Acta 1447, $160-174$.

18. Vabulas RM \& Hartl FU (2005) Protein synthesis upon acute nutrient restriction relies on proteasome function. Science $\mathbf{3 1 0}$, 1960-1963.

19. Fleming JV, Hay SM, Harries DN, et al. (1998) Effects of nutrient deprivation and differentiation on the expression of growth-arrest genes (gas and gadd) in F9 embryonal carcinoma cells. Biochem J 330, 573-579.

20. Schlessinger J (2000) Cell signaling by receptor tyrosine kinases. Cell 103, 211-225.

21. Maurer A, Wieland T, Meissl F, et al. (2005) The $\beta$-subunit of G proteins is a substrate of protein histidine phosphatase. Biochem Biophys Res Commun 334, 1115-1120.

22. Dovas A \& Couchman JR (2005) RhoGDI: multiple functions in the regulation of Rho family GTPase activities. Biochem J 390, $1-9$.

23. McNeil CJ, Hay SM, Rucklidge G, et al. (2009) Gene and protein expression profiles in the foetal liver of the pregnant rat fed a low protein diet. Gene Nutr (epublication ahead of print version 30 May 2009).

24. Bischoff FR, Krebber H, Kempf T, et al. (1995) Human RanGTPase-activating protein RanGAP1 is a homologue of yeast Rnalp involved in mRNA processing and transport. Proc Natl Acad Sci U S A 92, 1749-1753.

25. Fisher EA \& Ginsberg HN (2002) Complexity in the secretory pathway: the assembly and secretion of apolipoprotein b-containing lipoproteins. J Biol Chem 277, 17377-17380.

26. Qiu W, Kohen-Avramoglu R, Rashid-Kolvear F, et al. (2004) Overexpression of the endoplasmic reticulum 60 protein ER-60 downregulates ApoB100 secretion by inducing its intracellular degradation via a nonproteasomal pathway: evidence for an ER-60-mediated and pCMB-sensitive intracellular degradative pathway. Biochemistry 43, 4819-4831.

27. Gerke V \& Moss SE (2002) Annexins: from structure to function. Physiol Rev 82, 331-371.

28. Preiss D \& Sattar N (2008) Non-alcoholic fatty liver disease: an overview of prevalence, diagnosis, pathogenesis and treatment considerations. Clin Sci 115, 141-150.

29. Ravnskjaer K, Boergesen M, Rubi B, et al. (2005) Peroxisome proliferator-activated receptor $\alpha(\operatorname{PPAR} \alpha)$ potentiates, whereas PPAR $\gamma$ attenuates, glucose-stimulated insulin secretion in pancreatic $\beta$-cells. Endocrinology 146, 3266-3276.

30. Sandberg MB, Bloksgaard M, Duran-Sandoval D, et al. (2005) The gene encoding acyl-CoA-binding protein is subject to metabolic regulation by both sterol regulatory element-binding protein and peroxisome proliferator-activated receptor $\alpha$ in hepatocytes. J Biol Chem 280, 5258-5266.

31. Ameen C, Linden D, Larsson BM, et al. (2004) Effects of gender and GH secretory pattern on sterol regulatory elementbinding protein-1c and its target genes in rat liver. Am J Physiol Endocrinol Metab 287, E1039-E1048. 